\title{
BACTERIOLOGICAL ASSESSMENT OF SOME READY-TO-EAT FOODS
}

\author{
Naglaa, S. Hassan ${ }^{1}$; Seham, A. Esmail ${ }^{2}$ and Mahmoud, A. $H^{3}$. \\ ${ }^{1,2}$ Animal Health Research Institute, Giza branch \\ 3, Animal Health Research Institute, Dokki, Biotechnology Dept.
}

\begin{abstract}
A total of sixty random samples of grilled chicken, chicken luncheon, beef shawerma, beef burger, yoghurt and veta cheese (10 samples of each) were collected from different cafeterias in Giza Governorate and examined bacteriologically. Our study revealed presence of E. coli by ratio of 20\%, 10\%, 10\%, 20\% 10\% and zero $\%$ in the examined samples of grilled chicken, chicken luncheon, beef shawerma, beef burger, yoghourt and veta cheese respectively. Whereas Salmonella spp. were not detected, but Staph aureus spp. were detected by ratio of $40 \%, 10 \%, 20 \%, 30 \%, 20 \%$ and $20 \%$, respectively in the examined samples. While mean Yerisina were detected by ratio of $10 \%$ in each of grilled chicken, beef shawerma and beef burger samples but failed to be detected from the examined samples of chicken luncheon, yoghourt and veta cheese samples.
\end{abstract}

This study determined aerobic plate count, enterobacterial count, Bacillus cereus count and Staph aureus count in the examined samples.

\section{INTRODUCTION}

The first consumer right is to have a product of good quality and not constituting any health hazard. Poultry meat products are highly desirable, palatable, digestible and nutritious for all ages. 
A large number of many kinds of micro organisms such as E.coli, Salmonella, Staph. aureus and Yersina enterocolitica gain access to food from soil, water, hands and equipment during different stages of processing. Bacterial load becomes aggravated from utensils and meat additives such as spices, coloring matter and starch. By cooking at very high temperature for short time (grilling) all the vegetative bacteria die except those which form heat resistant spores. When condition become suitable (meat and chicken sandwiches kept at room temperature for long time) the growth rate of the germinating spores would be hight. The meat sandwiches (beef burger and beef shawerma) contains mainly after grilling the aerobic spore forming bacteria and Bacillus group that increase in count by time (Nassif et.al., 2002).

Certain members of aerobic spore forming organisms specially Bacillus cereus are reported in food poisoning outbreaks. Some spores will survive cooking and subsequently germinate into bacilli which under warm storage condition in cooked food, grow and produce toxins. The toxin responsible for the vomiting Syndrome is extremely heat resistant, it is not destroyed after one hour and half at $121^{\circ} \mathrm{c}$ (Hobbs and Roberts 1987 ).

Ready-to-eat products in which the level of Staph. aureus has reached $10^{6}$ /gm may cause illness while the presence of Salmonellae is considered a potentially hazardous (Soriano et. al., 2002).

Beef shawerma cooked on boilers attained temperature which were sufficient to kill vegetative bacteria on the surface of the meat and on the thin layer just bellow the surface but not in most internal region (Bryan, et. al. 1988). 
Yoghurt is one of the most unique, universal dairy product, highly nutrient, and easily digestible diet. Many enteropathogenic species have been found in milk, yoghurt and cheese stored under refrigerated temperatures. Post pasteurization contamination during manufacturing and handling, equipment, temperature abuse during transport and storage condition might result in high level of pathogenic organisms in cheese and yoghourt (Freitas et al., 1993).

Staphylococcus aureus count is an indicator of post processing cont-amination by the dairy industry (Flowers et al., 1992). In addition to Staphylococcus aureus produce toxin which causes vomiting and diarrhea. (Soriano et al., 2002).

Soft cheese and other dairy products have been caused staphylococcal food poisoning outbreak in Brazil and other countries. (Adesiyum et al., 1988; Bryan, et. al. 1988 and Almeida and Nader., 2000).

Microbiological standards for soft cheese were determined by National Health Department(ICSMF,1997)establishing counts for Staph.aureus of $10^{3} \mathrm{cfu} / \mathrm{g}$.

The present work aimed to examine some ready to eat foods including market chicken products (grilled and luncheon), meat products (shawerma and burger) and milk products (yoghurt and veta cheese) to evaluate their bacteriological quality and determine safety for consumer.

\section{MATERIAL AND METHOD}

\section{Collection of samples:}

A total of sixty random samples of ready to eat chicken, meat and dairy products (10 samples each of grilled chicken, chicken luncheon, beef shawerma, beef burger, yoghurt, and veta cheese) from different 
Cafeterias and fast food restaurants in Giza. The samples were directly transferred to the laboratory and subjected to the bacteriological examination.

\section{Preparation of samples:}

All collected samples were prepared according to technique recommended by (ICMSF, 1978).

\section{Microbiological examination:}

Prepared samples were examined for:

1- Aerobic plate count (A. P. C): the drop plated technique recommended by $\mathbf{I C M S F},(\mathbf{1 9 7 8 )}$ was applied using nutrient agar plates.

2- Total Enterobacteriacea count: according to (I.C.M.S.F,1978) using Brilliant green bile glucose agar.

3- Bacillus cereus count: as described by (Harrigan and Mecane, 1976) using Bacillus cereus selective agar.

4- Staphylococcus aureus count: according to (I.C.M.S.F, 1978) using Baird Parker medium.

5- Isolation and identification of $\boldsymbol{E}$. coli: as described by (I.C.M.S.F, 1978) and the isolates were identified Serologically by using diagnostic sera.

6- Isolation and identification of Salmonllae: as described by (Harvey and Price, 1987).

7- Isolation of coagulase positive Staphylococcus aureus : as described by (I.C.M.S.F,1978).

8-Isolation and identification of Yersinia entercolitica : as described by (АРHA, 1992). 


\section{RESULTS}

Table (1): Statistical analytical results of aerobic plate count in the examined samples.

\begin{tabular}{||l||c|c|c||}
\hline \multicolumn{1}{|c||}{ Samples } & \multicolumn{3}{c||}{ Aerobic count (cfu/g) } \\
\cline { 2 - 4 } & Min. & Max. & Mean \\
\hline \hline Grilled chicken & $1 \times 10^{3}$ & $6.2 \times 10^{6}$ & $6.3 \times 10^{5}$ \\
\hline Chicken luncheon & $<10^{2}$ & $4 \times 10^{6}$ & $4.7 \times 10^{5}$ \\
\hline Beef shawerma & $2 \times 10^{3}$ & $4 \times 10^{6}$ & $4.7 \times 10^{5}$ \\
\hline Beef burger & $3 \times 10^{2}$ & $6 \times 10^{5}$ & $7.1 \times 10^{4}$ \\
\hline Yoghurt & $5 \times 10^{2}$ & $3.6 \times 10^{4}$ & $1.2 \times 10^{4}$ \\
\hline Veta cheese & $3 \times 10^{2}$ & $2 \times 10^{4}$ & $3.6 \times 10^{3}$ \\
\hline
\end{tabular}

Table (2): Statistical analytical results of Enterobactereacae count in the examined samples.

\begin{tabular}{|c|c|c|c|}
\hline \multirow{2}{*}{ Samples } & \multicolumn{3}{|c|}{ Enterobactereacae count $(\mathrm{cfu} / \mathrm{g})$} \\
\hline & Min. & Max. & Mean \\
\hline Grilled chicken & $<10^{2}$ & $8 \times 10^{5}$ & $1 \times 10^{5}$ \\
\hline Chicken luncheon & $<10^{3}$ & $1 \times 10^{3}$ & $7.1 \times 10^{2}$ \\
\hline Beef shawerma & $<10^{2}$ & $6 \times 10^{4}$ & $1.9 \times 10^{4}$ \\
\hline Beef burger & $<10^{2}$ & $4 \times 10^{3}$ & $1 \times 10^{3}$ \\
\hline Yoghurt & $1 \times 10^{2}$ & $1 \times 10^{3}$ & $3.9 \times 10^{2}$ \\
\hline Veta cheese & $1 \times 10^{2}$ & $2 \times 10^{3}$ & $5.5 \times 10^{2}$ \\
\hline
\end{tabular}

Table (3): Statistical analytical results of Bacillus cereus count in the examined samples.

\begin{tabular}{|c|c|c|c|}
\hline \multirow{2}{*}{ Samples } & \multicolumn{3}{|c|}{ Bacillus cereus count (cfu/g) } \\
\hline & Min. & Max. & Mean \\
\hline Grilled chicken & $<10^{2}$ & $5.2 \times 10^{3}$ & $9.6 \times 10^{2}$ \\
\hline Chicken luncheon & $<10^{2}$ & $6 \times 10^{2}$ & $2.2 \times 10^{2}$ \\
\hline Beef shawerma & $<10^{2}$ & $4 \times 10^{3}$ & $8 \times 10^{2}$ \\
\hline Beef burger & $<10^{2}$ & $8 \times 10^{2}$ & $2.1 \times 10^{2}$ \\
\hline Yoghurt & $<10^{2}$ & $2 \times 10^{2}$ & $1 \times 10^{2}$ \\
\hline Veta cheese & $<10^{2}$ & $2 \times 10^{2}$ & $7 \times 10$ \\
\hline
\end{tabular}


Naglaa, S. Hassan et al.,

Table (4): Statistical analytical results of Staphylococcal aureus count in the examined samples.

\begin{tabular}{||l||c|c|c||}
\hline \multicolumn{1}{|c||}{ Samples } & \multicolumn{3}{c||}{ Staphylococcal count $(\mathbf{c f u} / \mathbf{g})$} \\
\cline { 2 - 4 } & Min. & Max. & Mean \\
\hline \hline Grilled chicken & $<10^{2}$ & $1 \times 10^{4}$ & $1.8 \times 10^{3}$ \\
\hline Chicken luncheon & $<10^{2}$ & $3 \times 10^{3}$ & $8.8 \times 10^{2}$ \\
\hline Beef shawerma & $<10^{2}$ & $6 \times 10^{3}$ & $1.7 \times 10^{3}$ \\
\hline Beef burger & $<10^{2}$ & $6 \times 10^{3}$ & $1 \times 10^{3}$ \\
\hline Yoghurt & $1 \times 10^{2}$ & $3 \times 10^{3}$ & $6.3 \times 10^{2}$ \\
\hline Veta cheese & $<10^{2}$ & $5 \times 10^{3}$ & $1.7 \times 10^{3}$ \\
\hline \hline
\end{tabular}

Table (5): Incidence of microorganisms isolated from examined ready to eat food samples.

\begin{tabular}{|c|c|c|c|c|c|c|c|c|}
\hline \multirow{2}{*}{ Samples } & \multicolumn{2}{|c|}{ E. coli } & \multicolumn{2}{|c|}{ Salmonellae } & \multicolumn{2}{|c|}{ Staph. aureus } & \multicolumn{2}{|c|}{ Yerisina } \\
\hline & No. & $\%$ & No. & $\%$ & No. & $\%$ & No. & $\%$ \\
\hline Grilled chicken & 2 & 20 & 0 & 0 & 4 & 40 & 1 & 10 \\
\hline Chicken luncheon & 1 & 10 & 0 & 0 & 1 & 10 & 0 & 0 \\
\hline Beef shawerma & 1 & 10 & 0 & 0 & 2 & 20 & 1 & 10 \\
\hline Beef burger & 2 & 20 & 0 & 0 & 3 & 30 & 1 & 10 \\
\hline Yoghurt & 1 & 10 & 0 & 0 & 2 & 20 & 0 & 0 \\
\hline Veta cheese & 0 & 0 & 0 & 0 & 2 & 20 & 0 & 0 \\
\hline
\end{tabular}

* E. coli strain for milk product : $\mathrm{O}_{119}: \mathrm{K}_{69}$ and $\mathrm{O}_{112}: \mathrm{K}_{66}$.

** E. coli strain for meat and chicken product : $\mathrm{O}_{26}: \mathrm{K}_{60}, \mathrm{O}_{55}: \mathrm{K}_{59}$ and $\mathrm{O}_{119}: \mathrm{K}_{69}$.

\section{DISCUSSION}

Table (1) showed that the mean value of total aerobic plate count in samples of grilled chicken, chicken luncheon, beef shawerma, beef burger, yoghurt and veta cheese were $6.3 \times 10^{5}, 4.7 \times 10^{5}, 4.7 \times 10^{5}, 7.1$ $\mathrm{x} 10^{4}, 1.2 \times 10^{4}$ and $3.6 \times 10^{3} \mathrm{cfu} / \mathrm{g}$ respectively. 
This study demonstrates that grilled chicken and chicken luncheon have the highest contamination load according to total bacterial count, these count in grilled chicken samples were higher than those obtained by Ahmed (1991), Hamid et al., (2008) who recorded that the total bacterial count in grilled chicken was $6.23 \times 10^{4} \mathrm{cfu} / \mathrm{g}$, but the results were lower than those obtained by $\boldsymbol{E l - K h a t e i b}$ et. al., (1988) who recorded a total bacterial count of $10^{7} / \mathrm{g}$ for chicken products and $10^{7} \mathrm{cfu} / \mathrm{g}$ for burger. Al-Dughaym et. al., (2003) revealed that the mean total bacterial count was $3.3 \times 10^{7} \mathrm{cfu} / \mathrm{g}$ for burger. Aerobic plate count in yoghurt also higher than the count $\left(9.5 \times 10^{3} \mathrm{cfu} / \mathrm{g}\right)$ recorded by Khalaf and Shareef (1985). WHO (2000) stated that the total aerobic bacterial count was the most reliable method for detection of sanitary processing or proper storage of ready-to-eat products.

On the other hand, the results obtained in table (2) show that the mean value of Enerobacteruaceae count was high $\left(1 \times 10^{5}\right.$ and $1.9 \times 10^{4}$ $\mathrm{cfu} / \mathrm{g}$ ) in both grilled chicken and beef shawerma and lower count $\left(7.1 \times 10^{2}, 1 \times 10^{3}, 3.9 \times 10^{2}\right.$ and $\left.5.5 \times 10^{2} \mathrm{cfu} / \mathrm{g}\right)$ were recorded for chicken luncheon, beef burger, yogurt and veta cheese. Enterobacteraceae are useful indicators of hygiene of post processing contamination of processed foods as those bacteria coming in cooked products from equipment or from contact with raw foods.

Also, it is clear from results that the mean values of Bacillus cereus count were $9.6 \times 10^{2}, 2.2 \times 10^{2}, 8 \times 10^{2}, 2.1 \times 10^{2}, 1 \times 10^{2}$ and $7 \times 10 \mathrm{cfu} / \mathrm{g}$ in the examined grilled chicken, chicken luncheon, beef shawerma, beef burger, yogurt and veta cheese samples, respectively (table 3). 
Moreover, the mean Staph. aureus count recorded were $1.8 \times 10^{3}$, $8.8 \times 10^{2}, 1.7 \times 10^{3}, 1 \times 10^{3}, 6.3 \times 10^{2}$ and $1.7 \times 10^{3} \mathrm{cfu} / \mathrm{g}$ in the examined grilled chicken, chicken luncheon, beef shawerma, beef burger, yogurt and veta cheese samples, respectively (table 4). These result were higher than that obtained by Al-Dughaym et al., (2003) who mentioned that Staph. aureus count from burger was less than $10^{2} \mathrm{cfu} / \mathrm{g}$. On the other hand,Khalaf and Shareef,(1985)recorded high count $\left(10^{3} \mathrm{~g}-1\right)$ in yoghurt.

Bacillus cereus and Staph. Aureus causes food poisoning. Staphylococcus spp are common environmental bacteria and thus could be introduced into the food after cooking through cross- contamination from utensils, the vendors' hands, dish, cloths. The presence of Bacillus spp and staphylococcus spp. indicate possible cross-contamination between food preparation surfaces and food itself(Francina and Alexander 2001).

E. coli were found in $20 \%$ of grilled chicken and beef burger samples and in $10 \%$ of chicken luncheon, beef shawerma and yoghurt, while veta cheese were free from E. coli (table 5). It is obvious that the examined samples of beef shawerma and chicken luncheon were contaminated with lower percentages which may be attributed to thermal curing process of the product which plays a great inhibitory effect on multiplication of M.O (Gobran, 1985). The presence of E. coli in meat products indicate fecal pollution and reflects the unsatisfactory hygienic condition during manufacturing and handling of these products. Gonzales et al (2000) have investigated $E$. coli colonies isolated from white soft cheese in $11.3 \%$ of cheese samples while Hamid (2008) detected E. coli in $5.5 \%$ of grilled chicken. 
E. coli other than $0_{157}: \mathrm{H}_{7}$ strain and Salmonella may have been introduced proper cooking, treatment during processing of such products which may be destroyed Salmonella probably existing in raw material (Bryan et al., 1968).

Table (5) showed that Staphylococcus aureus contamination were confirmed in $40 \%$ samples of grilled chicken, $30 \%$ of beef burger, $20 \%$ each of beef shawerma, yoghurt, and veta cheese and $10 \%$ of chicken luncheon. These results were higher that than obtained by Hamid (2008) who revealed that Staph. aureus and E. coli contamination were found in $14.2 \%$ and $12.6 \%$ of examined samples respectively. Tessi et.al. (2002) reported E. coli contamination in $6.34 \%$ of ready-to-eat cooked food samples.

Fang et.al.(2003) in Taiwan found that 17.9\%, 7.9\% of prepared ready-to-eat meat had staph. aureus, and E. coli respectively. Some strain of Staph. aureus produce enterotoxins that cause staphyloccal food poisoning (Wikpida, 2008).

Also, the results in table (5) revealed that Yersinia could be isolated from $10 \%$ of the examined grilled chicken, beef shawerma and beef burger, these results nearly similar to Logue et al., (1996). But Francina and Alexander (2001) failed to detect Yersinia in ready-to-eat meat, also Araijo et al., 2002 could not detected Yersinia in dairy product. Yersinia is a potential cause of food born disease in human infants the contamination related with inadequate cooking and cross contamination. occurrence of Yersinia spp. in food including raw or pasteurized milk and several byproduct such as cheese have been investigated in some countries (Moro and Nures, 1992). 


\section{CONCLUSION}

Results of this study showed high microbial counts in the examined ready to eat food samples which may be due to contamination during handling, inadequate sanitation, contaminated vegetables, long storage or fluctuated temperature during storage. This indicate a deficiency in management training, resulting in less food hygiene procedures and a lower standard of microbiological quality of the provided foods. The main factors for improving the quality of food are by decreasing handling contamination, good storage, proper processing, heat treatment, and proper management training for all workers and food processing steps.

\section{REFERENCE}

- Adesiyum, A.A.; Webb,L.A.; Romain, H.T. (1998): Prevalence and characteristics of Staphylococcus aureus strains isolated from bulk milk. J. food prot.; 61, 629-632.

- Advisory Committee on the Microbiological Safety of Food (ACMSF) (1995): Report on verocytotoxin-producing Escherichia-coli. London: HMSO.

- Ahmed, IM.I. (1991): Hygienic quality of marketed ready-to-eat meat. M. V. Sc. Thesis, Faculty of Vet. Med., Zagazig Univ.

- Al- Dughaym A., Altabari, G. F. and M. Hamdy (2003): Safety and quality of chicken products, Faculty of Veterinary Medicine and Animal Research, King Faisal University, Saudi Arabia.

- Almeida, F and Nader, F (2000): Occurrence of Staph. Aureus in cheese. Revista Da Saude publica, 34, 578-580. 
- American public Health Association (APHA) (1992): Compendium of Methods for the Microbial Examination of Foods. $2^{\text {nd }}$ edition American public Health Association, Washington, D.C.V.S.A.

- Araujo, V.A.; Pagliares, M.L. and Frietas,A.. (2002): Occurrence of Staphylococcus and Enterogens in soft chesse commercialized in the city of Rio de Janciro, Brazil. J. of appl. Microbiol.92, 1172-1177.

- Bryan, F. L.; Aynes, J. C. and Kraft, A. A. (1968): Destruction of salmonella and indicator organisms during thermal processing of Turkeu rolls. Poult. Sci 47. 1966-1978.

- Bryan, F.L., S.C. Michanie, P. Alvarez., and A. Paniagua. (1988): Critical control points of street - vended foods in the Dominican Republic. J. Food Prot. 51: 373-383.

- El-Khateib,T.;Abd El-Rahman,H.; Hamdy, M. and Lotfi, A. (1988): Poultry meat products in Egypt "Proximal chemical composition and microbiological quality" Fleischwirtsch 68, 6, 756-757.

- Fang TJ, Wei QK, Liao CW,Hung MJ,WTH.(2003): Microbiological quality of 18 degrees $\mathrm{C}$ ready-to-eat food products sold in Taiwan. Int J. Food Microbiol; 80 (3): 241-50.

- Flowers, R.S.; Andrews, W.; Ponnelly, C.W. and Koeniny, E (1992): Pathogens in milk and milk products. R.T. 103-200, Washington, D.C. American public health association.

- Francina M. Mosupye and Alexander Von Holy (2001): Microbiological quality and safety - vended foods in Johannesburgs, South Africa. Appl Environ. Microbiol, 67 (12): 5431-5436.

- Freitas,A.C.; Nunes, M.P.; Milhomen,A.M.and Ricciardi,I.D. (1993): occurrence and characterization of Aeromonas sp. In pasteurized milk. Brazil J. of food protect. 5,62-65. 
- Gobran, R.A. (1985): Enterobacteriacea in meat products in upper Egypt. M.V.SC., thesis, Assuit Univ.

- Gonzalez, A.g.; Andrade, J.R. and Tibana, A. (2000): Enteropathogenicity marker in E-coli strains isolated from soft cheese and poultry. Brazil food microbiology, 17,321-328.

- Hamid Reza Tava Koli, Majid Riazipour (2008): Microbial quality of cooked meat foods in Tehran University's Restaurants, Pakistan. J. of Med. Sci. Vol. 24 (4),595-599.

- Harrigan, W. F. and Mccane,M.F. (1976): Lab. Methods in food and dairy microbiology, Academic press, London, New York, San Francis.

- Harvey, R.W. and Price, T.H (1987): Comparison of selenite F, Muller Kuffmann tetrathionate and Rappaport for Salmonella isolation from chicken giblets and after pre- enrichment in buffered peptone water. J. Hyg. Comb., 87,219.

- Hobb, B.C and Roberts, D.(1987): Food poisoning and food hygiene. $5^{\text {th }}$ Ed. Edward Arnold, chapter 3and 6, pp 27-104.

- International Committee on Microbiological Specifications for Food (I.C.M.S.F)(1978): Microorganisms in foods, Their significance and methods of enumeration, $2^{\text {nd }}$ Ed. Univ. of Toronto press. Toronoto and Buffalo, Canada.

- International Commission on Microbiological Specifications for Foods (I.C.M.S.F)(1997): Microorganisms in foods, Blackie Academic and professional, London.

- Khalaf, S.H. and Shareef, A.F. (1985): The bacteriological quality of Kishfa and Yoghurt in Mosul city, Iraq. Food microbial. J.(2): 241242. 
- Logue, C. M., J. J. Sheridan, G. Wunters, D. A. McDowell, and Blair, I. S.(1996): Yersinia spp and numbers, with particular reference to $\mathrm{Y}$. enterocolitica bio/serotypes occurring On Isish meat and meat products, and the influence of alkali treatment on their isolation. Int. J. Food Microbiol. 33:257-274.

- Moro, E.P. and Nures, M.P. (1992): Yerenia spp., astudy of the biological characteristic of strains isolated from white cheese. Revista de microbiologia J. 23, 250-255.

- Nassif, M.R.M.A.; Enshrah, K.T.Mira and Naglaa, S.H.A. (2002): Sanitary evaluation of some ready to eat fast meals. J. Egypt. Vet. Med. Ass. 62 (1): 245-253.

- Soriano, J. M.; Blesa, J. Rico, H.; Molto, J.C. and Manes, J. (2002): Incidence of Staphylococcus aureus in meats from cafeterias. Laboratory of food chemistry and toxicology, F. of pharmacy, Univ. of Valencia, AV. Vicent Andres Estellae s/n 46100 Bur Jassot, Spain (2002).

- Tavakoli HR, Riazipour M. (2008): Microbial quality of cooked meat foods in Tehran Universities Restaurants. Pak J. Med Sci 2008; 24 (4): 595-599.

- Tessi MA, Ariooli EE, Pirovani ME, Vincenzini AZ, Sabbag NG, Costa SC, et al., (2002): Microbiological quality and safety of readyto-eat cooked foods from centralized school kitchen in Argentina. J food prot; 65 (4): 636-42.

- Wikipedia, H.T. (2008): Evaluation of coagulase activity and protein A production for identification of Staphylococcus aureus. J. of Food prot. 58:858- 860 .

- World Health Organization (WHO)(2000): Surveillance program for control of food -borne infection and intoxication in Europe. Wewslitter Wo, 63, March 2000. 


\section{التقييـم البكتـريولوجى لبعض الأطعمة السـابقة التجهيز}

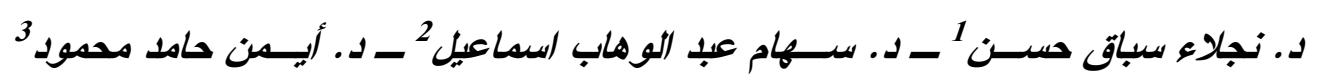

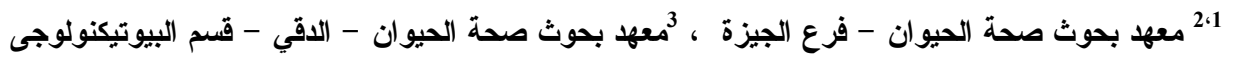

تم تجميع سنون عينة عشو ائية من المطاعم و الكافيتريات المنتشرة بمحافظة الجيزة. وكانت العينات عبارة عن عشرة عينات من كل من الدجاج المشوية، لنشن الدجاج، شورما اللحوم، برجر اللحوم، الزبادي و الجبن قيتا.

تم فحص هذه العينات بكتريولوجياً . أظهرت النتائج تلوث العينات بالأيشيريثياكو لاى بنسبة 20٪، 10\%10\%، 20٪ 10\% و صفر فى العينات السابقة على النو الي.

كما اثبت الفحص عدم تواجد ميكروب السالمونيلا بالعينات بينما نواجد الميكروب العنقودى الذهبى بنسبة ؛ 40٪، 10٪، 20٪، 30٪، 20\% و 20٪ على التوالي في العينات المجمعة. فى حين أن تم اكتشاف وجود اليرسينيا بنسبة 10٪ فى الدجاج المشوي، لحوم الثاورما ولحوم البرجر فقط.

وكذلك نم قياس العدد البكتيري الهو ائي وعدد الميكروبات المعوية وعدد ميكروب الباسيلس

سيرس وعدد الميكروب العنقودي الذهبي فى العينات. وقد تم مناقثة الأهمية الصحية للميكروبات المعزولة. 